\title{
Control of Curly Top in Sugar Beet with Seed and Foliar Insecticides
}

Carl A. Strausbaugh, United States Department of Agriculture-Agricultural Research Service (USDA-ARS) NWISRL; Erik J. Wenninger, University of Idaho, Kimberly Research and Extension Center; and Imad A. Eujayl, USDA-ARS NWISRL, Kimberly, ID 83341

\begin{abstract}
Strausbaugh, C. A., Wenninger, E. J., and Eujayl, I. A. 2014. Control of curly top in sugar beet with seed and foliar insecticides. Plant Dis. 98:10751080.

Curly top in sugar beet is a serious problem that is caused by Beet curly top virus and other closely related species and transmitted by the beet leafhopper. In order to find a means of reducing curly top in sugar beet, 15 combinations of insecticide seed (Poncho, Poncho Beta, and Poncho Votivo) and foliar (Asana, Cyazypyr, Lorsban, Mustang, Scorpion, and Sivanto) treatments were evaluated versus an untreated check during the 2012 and 2013 growing seasons. An epiphytotic was created by releasing viruliferous beet leafhoppers 58 to 59 days after planting. The foliar sprays were applied 6 to 7 days before and again 6

to 8 days after leafhopper release. Seed treatments (active ingredient: clothianidin) were able to reduce symptoms by 26 to $42 \%$ and increase recoverable sucrose by 16 to $21 \%$. The pyrethroids Asana and Mustang also performed well by reducing symptoms 22 to $56 \%$ and increasing yields 13 to $20 \%$. The neonicotinoid seed treatments should be an effective way of supplementing host resistance for early-season (at least 59 days after planting) curly top control in sugar beet. The pyrethroid foliar applications could be used to extend curly top control during the midseason period and provide resistance management.
\end{abstract}

Curly top is a viral disease problem in sugar beet (Beta vulgaris L.) that can lead to severe yield losses in semiarid production areas around the world (3). In the western United States, curly top in sugar beet can be attributed to any of three Curtovirus spp.-Beet severe curly top virus (BSCTV; formerly strain $\mathrm{CFH}$ ), Beet mild curly top virus (BMCTV; formerly strain Worland), and Beet curly top virus (BCTV; formerly strain Cal/Logan) —although sugar beet production areas outside the United States have been shown to possess additional strains or species $(8,22,29,33)$. Finding more than one of these three species in a commercial sugar beet plant is not unusual (29). Recent taxonomic revisions released by the International Committee on Taxonomy of Viruses (second version 25 March 2013) places the three species mentioned above under the species name BCTV (13). However, there are still discussions as to what strain designations should be used in place of the former species names. Thus, the species names have been used in this article.

BCTV is transmitted by the beet leafhopper, Circulifer tenellus (Baker), which disperses to production fields in the spring as weeds become desiccated in desert areas or poorly managed properties (3-5). If infection occurs at an early growth stage, damage is worse than if infection occurs at later growth stages $(6,19,32)$. Curly top almost eliminated sugar beet production in the western United States before resistant cultivars became available in the mid-1930s $(3,4)$. Host resistance is still one of the primary means to manage curly top in sugar beet but this resistance is difficult to maintain in commercial cultivars because it is quantitatively inherited $(9,12)$. When other desirable traits such as resistance to Beet necrotic yellow vein virus (causes rhizomania) and glyphosate

Corresponding author: C. A. Strausbaugh,

E-mail: Carl.Strausbaugh@ars.usda.gov

Mention of trade names or commercial products in this article is solely for the purpose of providing scientific information and does not imply recommendation or endorsement by the United States Department of Agriculture.

Accepted for publication 27 February 2014

http://dx.doi.org/10.1094/PDIS-12-13-1260-RE

This article is in the public domain and not copyrightable. It may be freely reprinted with customary crediting of the source. The American Phytopathological Society, 2014. were introduced into commercial cultivars, maintaining resistance to BCTV in the parental lines that were used to create the commercial hybrids proved to be problematic $(24,28)$. Currently, resistance in commercial sugar beet cultivars is only low to intermediate (24). These low levels of resistance seem to indicate that growers are willing to gamble on less resistance to maximize yield potential, while relying on other forms of protection such as insecticide seed treatments to control curly top.

In an effort to find a way to supplement host resistance, in-furrow, foliar, and seed-treatment insecticides have been investigated $(12,14,16,23,25,26,28,30)$. Based on these investigations, the neonicotinoid seed treatments (active ingredients: clothianidin and thiamethoxam) have shown the most potential to limit curly top and to increase yields $(23,25-28)$. Under low to moderate curly top pressure, the neonicotinoid seed treatments have been shown to increase yields by approximately $20 \%$ through providing earlyseason control of the beet leafhopper, the vector for BCTV (25). In some production areas in the western United States, the neonicotinoid seed treatments are now required on all sugar beet seed because of the low level of host resistance in commercial cultivars and the yield increases associated with the seed treatments (28). Though effective against beet leafhopper for at least 50 to 55 days after planting (28), the efficacy of seed treatments is expected to diminish over time. Thus, ways to extend control beyond the early-season period covered by the seed treatments needs to be investigated.

In Idaho, the use of foliar sprays in desert areas for beet leafhopper control was no longer justifiable by 1970 , because of costs, increasing urbanization near production fields, and influences on nontarget organisms (4). Previous studies with sugar beet would suggest that season-long control with foliar insecticides would not be possible because of their short efficacy period. However, there is a need for continuous control of this chronic problem from spring to fall (30), and extending control provided by seed treatments has not been investigated. Foliar insecticide treatments could potentially be used to extend protection and provide some midseason control after the seed treatments are no longer effective. Moreover, the use of non-neonicotinoid foliar insecticides as a supplement to seed treatments could contribute to insecticide resistance management for neonicotinoid chemistries. Thus, foliar insecticides were investigated with and without insecticide seed treatments to identify potential products that might reduce the influence of curly top in sugar beet through midseason control of the beet leafhopper virus vector. 


\section{Materials and Methods}

Treatments. In all, 15 insecticide seed and foliar treatments along with an untreated check (a total of 16 treatments) were evaluated on the commercial sugar beet 'B-42' (contact Betaseed Inc. for uncoded cultivar name) for their ability to control curly top. B-42 is among one of Idaho's more resistant cultivars for curly top, because it has a 2-year average rank of 6 of 28 commercial sugar beet cultivars evaluated for the Snake River Sugar Company during 2012 and 2013 (2013 Cultivar Performance Guide prepared for growers by C. A. Strausbaugh and O. T. Neher). The three insecticide seed treatments evaluated in the study were Poncho (clothianidin at $60 \mathrm{~g}$ a.i. per 100,000 seed; Bayer CropScience), Poncho Beta (clothianidin at $60 \mathrm{~g}$ a.i. $+\beta$-cyfluthrin at $8 \mathrm{~g}$ a.i. per 100,000 seed; Bayer CropScience), and Poncho Votivo 240FS (clothianidin at $60 \mathrm{~g}$ a.i. +10 MUI of Bacillus firmus I-1582 per 100,000 seed; Bayer CropScience). The six foliar insecticides (applied 6 to 7 days before and 6 to 8 days after release of viruliferous beet leafhoppers) were evaluated alone and in combination with a Poncho Beta seed treatment. The six foliar insecticide treatments were Scorpion 35SL (dinotefuran at $149 \mathrm{~g}$ a.i./ha; Gowan Co.), Sivanto 200SL (flupyradifurone at $204.6 \mathrm{~g}$ a.i./ha + Dyne-Amic at $0.5 \%$ [vol/vol]; Bayer CropScience), Lorsban 4E (chlorpyrifos at $561.6 \mathrm{~g}$ a.i./ha; Dow AgroSciences LLC), Cyazypyr (cyantraniliprole at $150 \mathrm{~g}$ a.i./ha; DuPont Crop Protection), Asana (esfenvalerate at $55.48 \mathrm{~g}$ a.i./ha; DuPont Crop Protection), and Mustang EC (zeta-cypermethrin at $56 \mathrm{~g}$ a.i./ha; FMC Corp.). The foliar and seed treatments represent a range of five different insecticide chemical classes: butenolides (Sivanto; Insecticide Resistance Action Committee [IRAC] group unknown), diamides (Cyazypyr; IRAC group 28), neonicotinoids (Poncho and Scorpion; IRAC group 4A), organophosphates (Lorsban; IRAC group 1B), and pyrethroids (Asana, Beta, and Mustang; IRAC group 3). The foliar sprays were applied with a $\mathrm{CO}_{2}$-powered backpack sprayer at $2.1 \mathrm{~kg} / \mathrm{cm}^{2}$ using a boom with a $8002 \mathrm{VS}$ spray nozzle (TeeJet Technologies) centered over each row. The sprayer was calibrated to release a volume of 168 liters/ha. To limit the influence of fungal pathogens and allow for good stand establishment, the fungicides Allegiance FL (metalaxyl at $15.6 \mathrm{~g}$ a.i. per $100 \mathrm{~kg}$ of seed; Bayer CropScience) and Thiram 42S (thiram at $250 \mathrm{~g}$ a.i. per $100 \mathrm{~kg}$ of seed; Bayer CropScience) were applied to all seed.

2012 Field plots. The 2012 study was established in a field located in Twin Falls County on the United States Department of Agriculture-Agricultural Research Service North Farm $\left(42^{\circ} 33.160^{\prime} \mathrm{N}, 114^{\circ} 21.188^{\prime} \mathrm{W}\right)$ near Kimberly, ID that had been in alfalfa the previous year and was disked and plowed in fall 2011. Fertilizer ( $\mathrm{N}$ at $100.8 \mathrm{~kg} / \mathrm{ha}$ and $\mathrm{P}_{2} \mathrm{O}_{5}$ at $123.3 \mathrm{~kg} / \mathrm{ha}$ ) was applied on 16 April and incorporated with a roller harrow. The 16 treatments were arranged in a randomized complete block design with eight replications. There were four-row plots that were $10.4 \mathrm{~m}$ long, with $56 \mathrm{~cm}$ between rows. Plots were planted on 24 April to a density of $352,272 \mathrm{seed} / \mathrm{ha}$ and thinned to 117,424 plants/ha on 4 June. Prior to thinning, a stand count was taken on 14 May when the plants had only cotyledons and no true leaves. Irrigation water was applied through handlines as needed to replace evapotranspiration based on data from the Twin Falls AgriMet station (station TWFI; elevation $1,197 \mathrm{~m}$; 42 $32.746^{\prime} \mathrm{N}, 11^{\circ} 20.762^{\prime} \mathrm{W} ; 0.93 \mathrm{~km}$ from plots). The crop was managed according to standard cultural practices mentioned in the Snake River Sugar Company sugar beet grower's guide book. On 6 June at the six-leaf growth stage, the percentage of plants with damage from the beet leafminer, $\mathrm{Pe}$ gomya betae Curtis (Diptera: Anthomyiidae), in the center two rows (an average of 68 plants per row) was recorded. Foliar sprays were applied on 15 June ( 7 days prior to beet leafhopper release) and repeated on 28 June ( 6 days after release). On 22 June (59 days after planting), approximately six viruliferous (reared on plants containing both BSCTV and BCTV) beet leafhoppers per plant were released by shaking them from cages over the whole plot area to ensure good curly top disease pressure, because only trace levels of natural curly top pressure were evident in this production area. The viruliferous beet leafhoppers came from the Beet Sugar Development Foundation insectary maintained in Twin Falls, ID. On 15 July, six symptomatic plants were arbitrarily sampled (three leaf punches per plant with the cap of a 2-ml microcentrifuge tube) to determine the Curtovirus spp. present in the plants. Plants in the center two rows (an average of 68 plants per row) of each plot were given a curly top rating using a disease index (15) of 0 to 9 (Table 1 ) in a continuous manner (all numbers between 0 and 9 were possible) on 15 August and 12 September. Other disease problems were not evident in the field during the growing season. To keep powdery mildew from developing, Microthiol Disperss (PA; sulfur at $4.48 \mathrm{~kg}$ a.i.; United Phosphorus Inc.) and Proline (prothioconazole at $175 \mathrm{~g}$ a.i./ha; Bayer CropScience) were applied on $29 \mathrm{Au}-$ gust. The center two rows were mechanically topped on 24 September and harvested with a small-plot harvester. During harvest, two eight-beet samples per plot were collected for sugar analysis (see "Sugar analysis and yield," below).

2013 Field plots. In 2013, the 2012 field experiment was repeated using field plots located in an adjacent field $\left(42^{\circ} 33.081^{\prime} \mathrm{N}\right.$, $114^{\circ} 21.363^{\prime} \mathrm{W}$ ) on the same farm. The trial was conducted with the same protocol except for some minor changes. The trial was planted on 23 April and thinned on 25 May. Prior to thinning, a stand count was taken on 15 May when the plants had only cotyledons and no true leaves. On 5 June (48 days after planting) at the six-leaf growth stage, the percentage of plants with leafminer damage in the center two rows (an average of 68 plants per row) was recorded. Six viruliferous beet leafhoppers per plant were released by shaking them from cages over the whole plot area on 20 June (58 days after planting) to create a severe curly top epiphytotic, because surrounding fields had only trace levels of infection. The foliar insecticides were applied on 14 June, 6 days prior to beet leafhopper release, and again on 28 June, 8 days after release. On 15 July, 10 plants were arbitrarily sampled (three leaf punches per plant with the cap of a 2-ml microcentrifuge tube) to establish the Curtovirus spp. present in the plants. Curly top in the center two rows (an average of 68 plants per row) was rated on 16 August and 11 September. Curly top was the only disease problem evident in

Table 1. Beet curly top disease rating system utilized by the Beet Sugar Development Foundation

\begin{tabular}{ll}
\hline Rating & \multicolumn{1}{c}{ Description of plant symptoms $^{\mathbf{z}}$} \\
\hline 0 & Healthy; no symptoms \\
1 & Vein clearing of heart leaves, slight pimpling of veins on the underside of leaves \\
2 & Slight leaf curl of the edges of new leaves; pimpling on the veins of the underside of the leaves \\
3 & Center few whorls of leaves with curling edges \\
4 & Most leaves moderately curling; more than half of the upper surface of the leaf visible \\
5 & Slight stunting, severe leaf curling; less than half of the upper leaf surface visible due to curling; most of the larger leaves still erect \\
6 & Stunting, slight yellowing; most leaves becoming prostrate \\
7 & Severe stunting, yellowing; leaves prostrate and some leaves dead \\
8 & Only the center few whorls of leaves green and alive \\
9 & Plant dead \\
\hline
\end{tabular}

${ }^{\mathrm{z}}$ Rating system was published by David Mumford in 1974 (15). The rating system was utilized in a continuous manner rather than categorically. Thus, any number, including decimal numbers, between zero and nine were possible when scoring the plants. 
the field during the growing season. The powdery mildew spray (Microthiol Disperss and Proline were applied in the same manner as in 2012) was applied on 10 July. The center two rows of each plot were harvested on 23 September.

Curtovirus spp. evaluation. In 2012 and 2013, 6 and 10 plants, respectively, were arbitrarily selected and sampled in mid-July to determine the species present in the trial. DNA extraction and polymerase chain reaction (PCR) were conducted with primers BSCTV-C1 2315F, BSCTV-C1 2740R, BMCTV-C1 2213F, BMCTV-C1 2609R, BCTV-C1 2097F, and BCTV-C1 2387R as described previously (29). Amplification products were electrophoresed through agarose gels (2\% wt/vol) supplemented with ethidium bromide $(0.0002 \mathrm{mg} / \mathrm{ml})$ in Tris-borate-EDTA buffer $(89$ $\mathrm{mM}$ Tris base, $89 \mathrm{mM}$ boric acid, and $2 \mathrm{mM}$ EDTA). DNA from CTS07-11ID (contains BCTV, BMCTV, and BSCTV) served as a positive control (29). Reactions without template DNA served as negative controls.

Sugar analysis and yield. Two eight-beet samples collected from each plot at harvest were submitted to the Snake River Sugar Company Tare Lab in Paul, ID. Percent sucrose was determined using an Autopol 880 polarimeter (Rudolph Research Analytical) and a half-normal weight sample dilution and aluminum sulfate clarification method (ICUMSA Method GS6-3 1994) (2). Conductivity was measured using a Foxboro conductivity meter model 871EC (Foxboro) and nitrate was measured using a multimeter model 250 (Denver Instruments) with Orion probes 900200 and 9300 BNWP (Krackler Scientific, Inc.). Estimated recoverable sucrose (ERS) yield per ton of roots was calculated using the following equation: [(extraction $) \times(0.01) \times($ gross sucrose $/$ ha $)] /(\mathrm{t} / \mathrm{ha})$, where extraction $=250+\{[(1255.2) \times($ conductivity $)-(15,000) \times$ (percent sucrose $-6,185)] /[($ percent sucrose $) \times(98.66-[(7.845) \times$ $($ conductivity $)])]\}$ and gross sucrose $=\{[(\mathrm{t} / \mathrm{ha}) \times($ percent sucrose $)]$ $\times(0.01)\} \times(1,000 \mathrm{~kg} / \mathrm{t})$. The mean of the two samples from each plot was used for analyses.

Data analysis. The SAS (version 9.2; SAS Institute Inc.) Univariate procedure was used to test for normality and Levene's test (HOVTEST = Levene) was used to determine homogeneity of variance. Data were subjected to analysis of variance using the
SAS generalized linear models procedure (Proc GLM). Initially, a two-way analysis of variance was conducted. If data sets across years could not be combined, a one-way analysis of variance was conducted. Mean comparisons were conducted using Fisher's protected least significant difference $(\alpha=0.05)$. Mean comparisons across treatments were conducted using single degree-of-freedom orthogonal contrast statements in SAS. Although the stand count occurred prior to the application of the foliar treatments, all plots were included in the stand evaluation and still treated as 16 individual treatments in the analysis.

\section{Results}

Stand. The stand data differed $(P=0.0002)$ between years; therefore, each year is reported separately (data not shown). In 2012 , the overall average stand was $61 \%$ (the percentage of seed that emerged $)$ and there were no differences $(P=0.5914)$ among treatments. In 2013, there were no differences $(P=0.0694)$ among treatments and the overall average stand was $71 \%$. In both years, the stand was sufficient to allow for desired plant spacing (15.24 $\mathrm{cm}$ ) after thinning.

Leafminer. The percentage of plants with beet leafminer differed $(P<0.0001)$ between years; therefore, each year is reported separately (data not shown). In 2012, 100\% of the untreated plants at the six-leaf growth stage were infested, whereas plants with an insecticide seed treatment showed no damage. In 2013, 86 to $90 \%$ of the untreated plants at the six-leaf growth stage were infested, while plants with an insecticide seed treatment had significantly $(P$ $<0.0001)$ less damage, with only a 0 to $1 \%$ infestation. The foliar insecticide applications occurred after the six-leaf growth stage; therefore, no comparison among foliar applications is presented. Natural infestation from insect pests other than beet leafminers was negligible during both years.

Curly top. The distribution of approximately six viruliferous beet leafhoppers per plant led to severe curly top epiphytotics in both years (Table 2). DNA testing indicated that BSCTV and BCTV were present in all 16 plants tested (6 tested in 2012 and 10 tested in 2013). One plant in 2013 contained three Curtovirus spp., including BMCTV. The positive and negative PCR checks per-

Table 2. Influence of insecticide seed and foliar treatments on curly top symptoms using the commercial sugar beet 'B-42' during the 2012 and 2013 growing seasons near Kimberly, ID

\begin{tabular}{|c|c|c|c|c|c|}
\hline \multirow[b]{2}{*}{ Insecticide seed treatment ${ }^{y}$} & \multirow[b]{2}{*}{ Foliar insecticide treatment } & \multicolumn{2}{|c|}{ August $^{\mathrm{x}}$} & \multicolumn{2}{|c|}{ September ${ }^{x}$} \\
\hline & & 2012 & 2013 & 2012 & 2013 \\
\hline Untreated check & Untreated check & $4.5 \mathrm{a}$ & $4.8 \mathrm{a}$ & $5.4 \mathrm{a}$ & $6.1 \mathrm{ab}$ \\
\hline Poncho & Untreated & $3.4 \mathrm{~d}-\mathrm{f}$ & $3.8 \mathrm{~b}$ & $4.3 \mathrm{c}-\mathrm{e}$ & $4.1 \mathrm{~d}-\mathrm{f}$ \\
\hline Poncho Beta & Untreated & $3.0 \mathrm{e}-\mathrm{h}$ & $3.8 \mathrm{~b}$ & $4.1 \mathrm{de}$ & $4.1 \mathrm{~d}-\mathrm{f}$ \\
\hline Poncho Votivo & Untreated & $3.7 \mathrm{~b}-\mathrm{e}$ & $3.8 \mathrm{~b}$ & $4.7 \mathrm{~b}-\mathrm{d}$ & $4.1 \mathrm{~d}-\mathrm{f}$ \\
\hline Untreated & Scorpion & $3.6 \mathrm{c}-\mathrm{e}$ & $4.6 \mathrm{a}$ & $4.4 \mathrm{c}-\mathrm{e}$ & $5.5 \mathrm{c}$ \\
\hline Poncho Beta & Scorpion & $2.6 \mathrm{gh}$ & $3.9 \mathrm{~b}$ & $3.9 \mathrm{e}-\mathrm{g}$ & $4.2 \mathrm{de}$ \\
\hline Untreated & Sivanto & $4.3 \mathrm{ab}$ & $5.0 \mathrm{a}$ & $5.2 \mathrm{ab}$ & $6.2 \mathrm{ab}$ \\
\hline Poncho Beta & Sivanto & $3.1 \mathrm{e}-\mathrm{g}$ & $3.9 \mathrm{~b}$ & $4.0 \mathrm{~d}-\mathrm{g}$ & $4.4 \mathrm{~d}$ \\
\hline Untreated & Lorsban & $3.9 \mathrm{a}-\mathrm{d}$ & $4.6 \mathrm{a}$ & $4.0 \mathrm{~d}-\mathrm{f}$ & $5.9 \mathrm{bc}$ \\
\hline Poncho Beta & Lorsban & $1.8 \mathrm{i}$ & $3.8 \mathrm{~b}$ & $2.5 \mathrm{~h}$ & $3.7 \mathrm{ef}$ \\
\hline Untreated & Cyazypyr & $4.2 \mathrm{a}-\mathrm{c}$ & $5.0 \mathrm{a}$ & $4.9 \mathrm{a}-\mathrm{c}$ & $6.7 \mathrm{a}$ \\
\hline Poncho Beta & Cyazypyr & $2.8 \mathrm{f}-\mathrm{h}$ & $3.9 \mathrm{~b}$ & $3.9 \mathrm{e}-\mathrm{g}$ & $4.1 \mathrm{~d}-\mathrm{f}$ \\
\hline Untreated & Asana & $2.7 \mathrm{f}-\mathrm{h}$ & $3.0 \mathrm{c}$ & $3.3 \mathrm{~g}$ & $2.7 \mathrm{~h}$ \\
\hline Poncho Beta & Asana & $2.7 \mathrm{f}-\mathrm{h}$ & $2.5 \mathrm{~cd}$ & $3.8 \mathrm{e}-\mathrm{g}$ & $2.9 \mathrm{gh}$ \\
\hline Untreated & Mustang & $3.4 \mathrm{~d}-\mathrm{f}$ & $3.0 \mathrm{c}$ & $4.2 \mathrm{c}-\mathrm{e}$ & $3.6 \mathrm{fg}$ \\
\hline Poncho Beta & Mustang & $2.2 \mathrm{hi}$ & $2.8 \mathrm{~d}$ & $3.4 \mathrm{fg}$ & $3.0 \mathrm{gh}$ \\
\hline Overall mean & $\ldots$ & 3.2 & 3.9 & 4.1 & $4.4^{\circ}$ \\
\hline$P>F^{z}$ & $\ldots$ & $<0.0001$ & $<0.0001$ & $<0.0001$ & $<0.0001$ \\
\hline LSD & $\ldots$ & 0.7 & 0.5 & 0.7 & 0.7 \\
\hline
\end{tabular}

${ }^{x}$ Curly top in the center two rows was rated on a scale of 0 to $9(0=$ healthy and $9=$ dead $)$ in a noncategorical manner (Table 1$)$. Means followed by the same letter did not differ based on Fisher's protected least significant difference (LSD) value with $\alpha=0.05$.

${ }^{\mathrm{y}}$ Insecticide seed treatments were Untreated $=$ no insecticide treatment; Poncho $=$ clothianidin at $60 \mathrm{~g}$ a.i. per 100,000 seed; Poncho Beta $=$ clothianidin at 60 g a.i. $+\beta$-cyfluthrin at $8 \mathrm{~g}$ a.i. per 100,000 seed; and Poncho Votivo 240FS = clothianidin at $60 \mathrm{~g}$ a.i. +10 MUI of Bacillus firmus I-1582 per 100,000 seed. The foliar treatments were Scorpion $35 \mathrm{SL}=$ dinotefuran at $149 \mathrm{~g}$ a.i./ha; Sivanto $200 \mathrm{SL}=$ flupyradifurone at $204.6 \mathrm{~g}$ a.i./ha + Dyne-Amic at $0.5 \% \mathrm{vol} / \mathrm{vol}$; Lorsban $4 \mathrm{E}=$ chlorpyrifos at $561.6 \mathrm{~g}$ a.i./ha; Cyazypyr $=$ cyantraniliprole at $150 \mathrm{~g}$ a.i./ha; Asana $=$ esfenvalerate at $55.48 \mathrm{~g}$ a.i./ha; and Mustang EC $=$ zetacypermethrin $56 \mathrm{~g}$ a.i./ha. The foliar insecticide treatments were applied twice (6 to 7 days prior to hopper release and repeated 6 to 8 days after hopper release).

${ }^{\text {z }} P>F$ was the probability associated with the $F$ value. 
formed as expected. The curly top data for both August $(P=$ $0.0002)$ and September $(P=0.0085)$ differed between years; therefore, each year is reported separately (Table 2). In August 2012, all treatments had lower ratings than the untreated check, except for the foliar-only treatments of Cyazypyr, Lorsban, and Sivanto. In August 2013, all treatments had lower ratings than the untreated check, except for the foliar-only treatments of Cyazypyr, Lorsban, Scorpion, and Sivanto. Based on August orthogonal contrasts (all nine treatments with Poncho versus those with no seed treatment) in both 2012 and 2013, Poncho-treated seed lowered $(P<0.0001)$ the curly top rating ( 2.59 and 3.54 , respectively) compared with untreated seed (3.80 and 4.28, respectively). Compared with the untreated check in August using orthogonal contrasts, Ponchotreated seed (all nine treatments) reduced $(P<0.0001)$ the curly top rating by 1.91 and 1.26 in 2012 and 2103, respectively. In September 2012 and 2013, all treatments had lower ratings than the untreated check, except for the foliar-only treatments of Cyazypyr and Sivanto. Based on September contrasts (all nine treatments with Poncho versus those with no seed treatment) in both 2012 and 2013, Poncho-treated seed lowered $(P<0.0001)$ the curly top rating (3.65 and 3.84, respectively) compared with untreated seed (4.49 and 5.24, respectively). Compared with the untreated check in September using orthogonal contrasts, Poncho-treated seed (all nine treatments) reduced $(P<0.0001)$ the curly top rating by 1.75 and 2.26 in 2012 and 2103, respectively.

Yield variables. Root yield, sucrose content, and ERS differed between years $(P=0.0008, P<0.0001$, and $P=0.0003$, respectively); therefore, data were analyzed and presented by year (Table 3). Root yield in 2012 was higher for all treatments compared with the untreated check, except for the foliar-only treatments of Cyazypyr and Sivanto. In 2013, the foliar-only treatments Cyazypyr, Sivanto, Lorsban, and Scorpion did not differ from the untreated check. In 2012, treatments with Poncho (all nine treatments) and the foliar-only treatments Asana and Mustang resulted in the highest root yields. In 2013, the Poncho treatments (all nine) and Asana and Mustang with and without Poncho resulted in the highest root yields. Based on orthogonal contrasts in both 2012 and 2013, Poncho-treated seed (all nine treatments) increased $(P<$ 0.0001 ) root yield by 14.19 and $19.19 \mathrm{t} / \mathrm{ha}$, respectively, compared with the untreated check. Sucrose content did not differ among treatments in either $2012(P=0.2091)$ or $2013(P=0.7493)$. ERS in 2012 and 2013 was higher for all treatments compared with the untreated check, except for the foliar-only treatments of Cyazypyr, Lorsban, and Sivanto. In 2013, the Scorpion only treatment also did not differ from the untreated check. Based on orthogonal contrasts in both 2012 and 2013, Poncho-treated seed (all nine treatments) increased $(P<0.0001)$ ERS by 2,088 and $2,202 \mathrm{~kg} / \mathrm{ha}$, respectively compared with the untreated check.

\section{Discussion}

The Poncho seed treatments (all nine) were effective at controlling severe curly top pressure 58 to 59 days after planting and led to a 16 and $21 \%$ increase in root yield compared with the untreated check in 2012 and 2013, respectively. The Poncho seed treatments (all nine) also led to a 18 and $21 \%$ increase in recoverable sucrose compared with the untreated check in 2012 and 2013, respectively, which is consistent with previous results $(25,28)$. Compared with the untreated check in August, the Poncho seed treatments (all nine) reduced the curly top rating by 42 and $26 \%$ in 2012 and 2103, respectively. Compared with the untreated check in September, the Poncho seed treatments (all nine) reduced the curly top rating by 32 and $37 \%$ in 2012 and 2103, respectively. When comparing the foliar treatments without an insecticide seed treatment during September, Asana reduced the curly top rating 39 to $56 \%$ and performed better than the other nonpyrethroid foliar treatments during both years. The other pyrethroid foliar treatment (Mustang) also performed well but its curly top rating was always significantly higher than Asana in September in both years. When evaluating recoverable sucrose, the two pyrethroid treatments were also the topranking foliar-only treatments but did not differ from each other. In 2013, the pyrethroids led to significantly more recoverable sucrose than all other foliar treatments and were the only foliar treatments to consistently increase yield over both years. When the pyrethroids were combined with the Poncho Beta seed treatment, these two treatments were among the top three ranked treatments for recoverable sucrose during both years but were not significantly different from each other. Thus, the Poncho seed treatments appear to be a good early-season (at least until 59 days after planting)

Table 3. Influence of insecticide seed (IS) and foliar insecticide (FI) treatments on yield variables using the commercial sugar beet 'B-42' during the 2012 and 2013 growing seasons near Kimberly, ID ${ }^{\mathrm{w}}$

\begin{tabular}{|c|c|c|c|c|c|c|c|}
\hline \multirow[b]{2}{*}{ IS treatment ${ }^{y}$} & \multirow[b]{2}{*}{ FI treatment } & \multicolumn{2}{|c|}{ Root yield (t/ha) } & \multicolumn{2}{|c|}{ Sucrose content $(\%)$} & \multicolumn{2}{|c|}{$\operatorname{ERS~}(\mathrm{kg} / \mathrm{ha})^{\mathrm{x}}$} \\
\hline & & 2012 & 2013 & 2012 & 2013 & 2012 & 2013 \\
\hline Untreated check & Untreated check & $87.25 \mathrm{~d}$ & $92.09 \mathrm{fg}$ & 15.35 & 13.32 & 11,668 ef & $10,501 \mathrm{ef}$ \\
\hline Poncho & Untreated & $99.55 \mathrm{ab}$ & $112.85 \mathrm{a}-\mathrm{d}$ & 15.59 & 13.55 & $13,365 \mathrm{a}-\mathrm{c}$ & $12,911 \mathrm{ab}$ \\
\hline Poncho Beta & Untreated & $101.82 \mathrm{a}$ & $108.77 \mathrm{~cd}$ & 15.46 & 13.52 & $13,567 \mathrm{a}-\mathrm{c}$ & $12,480 a-c$ \\
\hline Poncho Votivo & Untreated & $99.04 \mathrm{ab}$ & $110.58 \mathrm{~b}-\mathrm{d}$ & 15.34 & 13.44 & $13,151 \mathrm{~b}-\mathrm{d}$ & $12,651 \mathrm{a}-\mathrm{c}$ \\
\hline Untreated & Scorpion & $97.60 \mathrm{ab}$ & 99.08 ef & 15.50 & 13.42 & $13,111 \mathrm{~b}-\mathrm{d}$ & $11,286 \mathrm{de}$ \\
\hline Poncho Beta & Scorpion & $101.17 \mathrm{a}$ & $106.73 \mathrm{de}$ & 15.75 & 13.42 & $13,802 \mathrm{ab}$ & $12,150 \mathrm{~b}-\mathrm{d}$ \\
\hline Untreated & Sivanto & $86.08 \mathrm{~d}$ & $85.81 \mathrm{~g}$ & 15.22 & 13.51 & $11,378 \mathrm{f}$ & $9,973 \mathrm{f}$ \\
\hline Poncho Beta & Sivanto & $101.15 \mathrm{a}$ & $104.51 \mathrm{de}$ & 15.66 & 13.29 & $13,766 \mathrm{ab}$ & $11,685 \mathrm{~cd}$ \\
\hline Untreated & Lorsban & $94.55 \mathrm{bc}$ & $87.63 \mathrm{~g}$ & 15.59 & 13.34 & $12,636 \mathrm{c}-\mathrm{e}$ & $9,973 \mathrm{f}$ \\
\hline Poncho Beta & Lorsban & $100.09 \mathrm{ab}$ & $109.93 \mathrm{~b}-\mathrm{d}$ & 15.93 & 13.46 & $13,681 \mathrm{ab}$ & $12,597 \mathrm{a}-\mathrm{c}$ \\
\hline Untreated & Cyazypyr & $90.65 \mathrm{~cd}$ & $83.55 \mathrm{~g}$ & 15.67 & 13.54 & $12,253 \mathrm{~d}-\mathrm{f}$ & $9,805 \mathrm{f}$ \\
\hline Poncho Beta & Cyazypyr & $100.94 \mathrm{a}$ & $110.54 \mathrm{~b}-\mathrm{d}$ & 15.49 & 13.56 & $13,452 \mathrm{a}-\mathrm{c}$ & $12,863 \mathrm{ab}$ \\
\hline Untreated & Asana & $102.71 \mathrm{a}$ & $117.69 \mathrm{a}-\mathrm{c}$ & 15.91 & 13.17 & $14,015 \mathrm{ab}$ & $13,139 \mathrm{ab}$ \\
\hline Poncho Beta & Asana & $102.76 \mathrm{a}$ & $117.91 \mathrm{ab}$ & 15.68 & 13.50 & $13,874 \mathrm{ab}$ & $13,461 \mathrm{a}$ \\
\hline Untreated & Mustang & $99.42 \mathrm{ab}$ & $112.22 \mathrm{a}-\mathrm{d}$ & 15.62 & 13.52 & $13,354 \mathrm{a}-\mathrm{c}$ & $12,944 \mathrm{ab}$ \\
\hline Poncho Beta & Mustang & $102.13 \mathrm{a}$ & $119.73 \mathrm{a}$ & 15.94 & 13.49 & $14,151 \mathrm{a}$ & $13,525 \mathrm{a}$ \\
\hline Overall mean & $\ldots$ & 97.94 & 104.98 & 15.61 & 13.44 & 13,201 & 11,996 \\
\hline$P>F^{\mathrm{z}}$ & $\ldots$ & $<0.0001$ & $<0.0001$ & 0.2091 & 0.7493 & $<0.0001$ & $<0.0001$ \\
\hline LSD & $\ldots$ & 5.76 & 8.99 & NS & NS & 999 & 1,105 \\
\hline
\end{tabular}

${ }^{\text {w}}$ Means followed by the same letter did not differ based on Fisher's protected least significant difference (LSD) value with $\alpha=0.05$. NS $=$ not significant.

${ }^{x}$ ERS $=$ estimated recoverable sucrose.

${ }^{y}$ IS treatments were Untreated $=$ no insecticide treatment; Poncho $=$ clothianidin at $60 \mathrm{~g}$ a.i. per 100,000 seed; Poncho Beta $=$ clothianidin at $60 \mathrm{~g}$ a.i. $+\beta$ cyfluthrin at $8 \mathrm{~g}$ a.i. per 100,000 seed; and Poncho Votivo 240FS = clothianidin at $60 \mathrm{~g}$ a.i. +10 MUI of Bacillus firmus I-1582 per 100,000 seed. FI treatments were Scorpion 35SL = dinotefuran at $149 \mathrm{~g}$ a.i./ha; Sivanto $200 \mathrm{SL}=$ flupyradifurone at $204.6 \mathrm{~g}$ a.i./ha + Dyne-Amic at $0.5 \% \mathrm{vol} / \mathrm{vol} ; \mathrm{Lorsban}$ $4 \mathrm{E}=$ chlorpyrifos at $561.6 \mathrm{~g}$ a.i./ha; Cyazypyr $=$ cyantraniliprole at $150 \mathrm{~g}$ a.i./ha; Asana $=$ esfenvalerate at $55.48 \mathrm{~g}$ a.i./ha; and Mustang EC $=$ zetacypermethrin $56 \mathrm{~g}$ a.i./ha. The FI treatments were applied twice ( 6 to 7 days prior to hopper release and repeated 6 to 8 days after hopper release).

${ }^{\text {z }} P>F$ was the probability associated with the $F$ value. 
management option to supplement host resistance for the control of curly top in sugar beet. The pyrethroids (Asana and Mustang) would be an effective approach to provide short-term midseason control of beet leafhoppers and an insecticide resistance management tool.

Host resistance has been the primary means of controlling curly top in sugar beet since it was introduced in the mid-1930s $(3,4)$. However, host resistance is quantitatively inherited and, therefore, difficult to maintain in parental lines used to produce the commercial hybrids $(9,12)$. The cultivar used in this study is among the most resistant available in the United States. In this study, B-42 was exposed to curly top 58 to 59 days after planting (plants were beyond the eight-leaf growth stage), which should have given plants of this cultivar a good chance to withstand curly top disease pressure. Yet curly top ratings in September in the untreated check were 5.4 and 6.1, which is past halfway on the disease scale of 0 to 9. Given that this is one of the more resistant cultivars available in the United States, there is plenty of room for both improving and supplementing host resistance.

In an effort to supplement host resistance, neonicotinoid seed treatments $(23,25-28)$ have been successfully used to ameliorate curly top, beginning with the 2006 growing season. Some commercial production areas experienced large yield increases $(20 \%$ or more) and the neonicotinoid seed treatments are now required on all commercial sugar beet seed in some of these growing areas (28). Given the large increases in yield achieved even with the most resistant commercial sugar beet cultivars, it would appear that there will be a need for supplementing host resistance with seed treatments for years to come. Previous studies showed that the neonicotinoid seed treatments were effective up to 55 days after planting (28). This study shows that the early-season efficacy period can be extended to at least 59 days after planting, even with severe curly top pressure. Although there was early-season leafminer pressure, the effects of leafminer on yield in sugar beet are poorly studied (28). There are no established economic thresholds for leafminer in sugar beet. It would appear that the yield responses in this study primarily reflect the control of curly top, because they mirror the reduction in curly top ratings. To determine the influence of leafminer on yield, it should be studied without the overwhelming influence of curly top.

Despite the widespread use of neonicotinoid products for pest control, reported cases of resistance have been relatively manageable or geographically localized $(1,7,10,11,17,18,20,21,31)$. However, given the importance of the neonicotinoid seed treatments for reducing curly top and that all seed in some areas require the seed treatments, incorporating a resistance management program into sugar beet production should be considered. A foliar application of an insecticide chemistry different from neonicotinoids should be considered in sugar beet production. Because the seed treatments provide only early-season control, finding an alternative chemistry for midseason control would be inviting. The two pyrethroids evaluated in this study both appear to be good choices for supplementing resistance, although the September curly top ratings indicate that Asana should be favored over Mustang. Asana was also the highest-ranking foliar treatment for recoverable sucrose in both years. A foliar insecticide application 60 days after planting coincides closely with when the last glyphosate application for weed control would be applied. Thus, combining weed control with insect control would be an economical means to treat sugar beet plants. If rasping or chewing pests such as sugar beet root maggots or cutworms are a concern early in the season, applying one of these pyrethroids in combination with early-season glyphosate applications would be another possibility for economically supplementing pest and resistance management. The neonicotinoid seed treatments should also provide early-season pest management against other pests such as the beet leafminer (as noted in this study and previous studies) and black bean aphids $(23,27)$. In Idaho, the general pest control provided by the neonicotinoids more than justifies the cost of the seed treatment (approximately $\$ 57$ per hectare), because a 3.1- to 6.7-t/ha yield increase has been observed even without curly top pressure (23).
Season-long control of curly top with foliar insecticide applications was unsuccessful or only marginally successful when evaluated previously (30). Season-long control (6 to 7 months) or at least early-season control for curly top in sugar beet with foliar insecticides under Idaho conditions had not been investigated and the data presented here only address control for an infestation at one point in time. However, for fields in which rasping or chewing insect pests early in the season are a big concern, a program that incorporates a pyrethroid with glyphosate applications will likely help with supplementing curly top control. However, the continual application of nonsystemic, neurotoxic insecticides is especially detrimental to populations of arthropod natural enemies of insect pests. Thus, the curly top control provided by neonicotinoid seed treatments will be difficult to improve on with current technology when expecting continuous control throughout the early-season growth period.

\section{Acknowledgments}

These data support the objectives for the United States Department of Agriculture CRIS project 5368-21220-004-00D. We thank the Snake River Sugar Company; Beet Sugar Development Foundation; and Snake River sugar beet growers for supporting our research work; and J. Reed, D. Kenney, T. Brown, N. Perdomo, V. Adamson, M. Williams, and A. Carroll for their technical support efforts.

\section{Literature Cited}

1. Alyokhin, A., Dively, G., Patterson, M., Castaldo, C., Rogers, D., Mahoney, M., and Wollam, J. 2007. Resistance and cross-resistance to imidacloprid and thiamethoxam in the Colorado potato beetle Leptinotarsa decemlineata. Pest Manage. Sci. 63:32-41.

2. Bartens, A. 2005. International Commission for Uniform Methods of Sugar Analysis Methods Book 2005. Dr. Albert Bartens KG, Berlin.

3. Bennett, C. W. 1971. The curly top disease of sugarbeet and other pests. Monogr. No. 7. American Phytopathological Society, St. Paul, MN.

4. Blickenstaff, C. C., and Traveller, D. 1979. Factors affecting curly top damage to sugarbeets and beans in southern Idaho, 1919-77. Science and Education Administration, Agricultural Reviews and Manuals, Western Series, Number 8. U. S. Dep. Agric. Agric. Res. Serv. Oakland, CA.

5. Creamer, R., Luque-Williams, M., and Howo, M. 1996. Epidemiology and incidence of beet curly top geminivirus in naturally infected weed hosts. Plant Dis. 80:533-535.

6. Duffus, J. E., and Skoyen, I. O. 1977. Relationship of age of plants and resistance to a severe isolate of the beet curly top virus. Phytopathology 67:151-154.

7. Foster, S. P., Cox, D., Oliphant, L., Mitchinson, S., and Denholm, I. 2008. Correlated responses to neonicotinoid insecticides in clones of the peachpotato aphid, Myzus persicae (Hemiptera: Aphididae). Pest Manage. Sci. 64:1111-1114.

8. Gharouni Kardani, S., Heydarnejad, J., Zakiaghl, M., Mehrvar, M., Kraberger, S., and Varsani, A. 2013. Diversity of Beet curly top Iran virus isolated from different hosts in Iran. Virus Genes 46:571-575.

9. Gillen, A. M., Strausbaugh, C. A., and Tindall, K. V. 2008. Evaluation of Beta corolliflora for resistance to curly top in Idaho. J. Sugar Beet Res. 45:99-118.

10. Gorman, K., Liu, Z., Denholm, I., Brüggen, K.-U., and Nauen, R. 2008. Neonicotinoid resistance in rice brown planthopper, Nilaparvata lugens. Pest Manage. Sci. 64:1122-1125.

11. Jeschke, P., and Nauen, R. 2008. Neonicotinoids-from zero to hero in insecticide chemistry. Pest Manage. Sci. 64:1084-1098.

12. Kaffka, S. R., Wintermantel, W. M., and Lewellen, R. T. 2002. Comparisons of soil and seed applied systemic insecticides to control Beet curly top virus in the San Joaquin Valley. J. Sugar Beet Res. 39:59-74.

13. King, A. M. Q., Lefkowitz, E., Adams, M. J., and Carstens, E. B., eds. 2011. Virus Taxonomy: Ninth Report of the International Committee on Taxonomy of Viruses. Elsevier/Academic Press, Waltham, MA

14. Malm, N. R., and Finkner, R. E. 1968. The use of systemic insecticides to reduce the incidence of curly top virus disease in sugarbeets. J. Am. Soc. Sugar Beet Technol. 15:246-254.

15. Mumford, D. L. 1974. Procedure for inducing curly top epidemics in field plots. J. Am. Soc. Sugar Beet Technol. 18:20-23.

16. Mumford, D. L., and Griffin, G. D. 1973. Evaluation of systemic pesticides in controlling sugarbeet leafhopper. J. Am. Soc. Sugar Beet Technol. 17:354-357.

17. Nauen, R., and Denholm, I. 2005. Resistance of insect pests to neonicotinoid insecticides: current status and future prospects. Arch. Insect Biochem. Physiol. 58:200-215.

18. Nauen, R., Denholm, I., Dennehy, T., and Nichols, R. 2008. News from the front line: reports from the global workshop on the stewardship on neonicotinoid insecticides, Honolulu, Hawaii, 5-6 June 2008. Pest Manage. Sci. 64:1082-1083. 
19. Ritenour, G., Hills, F. J., and Lange, W. H. 1970. Effect of planting date and vector control on the suppression of curly top and yellows in sugarbeet. J. Am. Soc. Sugar Beet Technol. 16:78-84.

20. Shi, X., Jiang, L., Wang, H., Qiao, K., Wang, D., and Wang, K. 2011. Toxicities and sublethal effects of seven neonicotinoid insecticides on survival, growth and reproduction of imidacloprid-resistant cotton aphid, Aphis gossypii. Pest Manage. Sci. 67:1528-1533.

21. Slater, R., Paul, V. L., Andrews, M., Garbay, M., and Camblin, P. 2011. Identifying the presence of neonicotinoid-resistant peach-potato aphid (Myzus persicae) in the peach-growing regions of southern France and northern Spain. Pest Manage. Sci. Online publication. doi:10.1002/ps.2307

22. Stenger, D. C., and McMahon, C. L. 1997. Genotypic diversity of beet curly top virus populations in the western United States. Phytopathology 87:737744.

23. Strausbaugh, C. A., Eujayl, I. A., and Foote, P. 2010. Seed treatments for the control of insects and diseases in sugarbeet. J. Sugar Beet Res. 47:105125 .

24. Strausbaugh, C. A., Gillen, A. M., Camp, S., Shock, C. C., Eldredge, E. P., and Gallian, J. J. 2007. Relationship of beet curly top foliar ratings to sugar beet yield. Plant Dis. 91:1459-1463.

25. Strausbaugh, C. A., Gillen, A. M., Gallian, J. J., Camp, S., and Stander, J. R. 2006. Influence of host resistance and insecticide seed treatments on curly top in sugar beets. Plant Dis. 90:1539-1544.
26. Strausbaugh, C. A., Rearick, E., and Camp, S. 2008. Influence of curly top and Poncho Beta on storability of sugarbeet. J. Sugar Beet Res. 45:31-47.

27. Strausbaugh, C. A., Rearick, E., Eujayl, I. A., and Foote, P. 2010. Effect of insecticide seed treatments on sugarbeet storability. J. Sugar Beet Res. 47:65-88.

28. Strausbaugh, C. A., Wenninger, E. J., and Eujayl, I. A. 2012. Management of severe curly top in sugar beet with insecticides. Plant Dis. 96:1159-1164.

29. Strausbaugh, C. A., Wintermantel, W. M., Gillen, A. M., and Eujayl, I. A 2008. Curly top survey in the western United States. Phytopathology 98:1212-1217.

30. Wang, H., Gurusinghe, P. de A., and Falk, B. W. 1999. Systemic insecticides and plant age affect beet curly top virus transmission to selected host plants. Plant Dis. 83:351-355.

31. Wang, Y., Chen, J., Zhu, Y. C., Ma, C., Huang, Y., and Shen, J. 2008. Susceptibility to neonicotinoids and risk of resistance development in the brown planthopper, Nilaparvata lugens (Stål) (Homoptera: Delphacidae). Pest Manage. Sci. 64:1278-1284.

32. Wintermantel, W. M., and Kaffka, S. 2006. Sugar beet performance with curly top is related to virus accumulation and age at infection. Plant Dis. 90:657-662.

33. Yazdi, H. R. B., Heydarnejad, J., and Massumi, H. 2008. Genome characterization and genetic diversity of beet curly top Iran virus: a geminivirus with a novel nonanucleotide. Virus Genes 36:539-545. 